\title{
Dietary supplementation with Punica and Physalis attenuates the deleterious effects of fenitrothion in rats. \\ Rasha Abdel-Ghany ${ }^{1}$, Ebaa Mohammed ${ }^{1, \#, ~ S h i m a a ~ A n i s ~}{ }^{1, \#}$, Ahmed Bihery ${ }^{2}$ and Waleed Barakat $^{1,3, *}$ \\ ${ }^{1}$ Department of Pharmacology \& Toxicology, Faculty of Pharmacy, Zagazig University, Egypt. ${ }^{2}$ Department of Tropical Medicine, Faculty of Medicine, Zagzig University, Egypt. ${ }^{3}$ Department of Pharmacology \& Toxicology, Faculty of Pharmacy, Tabuk University, Kingdom of Saudi Arabia. \# Equal contribution. \\ * Corresponding author Email: waled055@ yahoo.com
}

\section{ABSTRACT:}

Exposure to pesticides may result in several health hazards including liver impairment which might be followed by impairment of brain functions or renal functions.

The current study was designed to test the beneficial effects of dietary supplement with Physalis peruviana and Punica granatum against toxicity induced by fenitrothion. The toxic effect of fenitrothion, $10 \mathrm{mg} / \mathrm{kg} / \mathrm{day}$, orally for 28 day) on liver, brain and kidney functions and the prophylactic effect of daily Physalis $(15 \%$ of diet) and Punica $(3 \mathrm{ml} / \mathrm{kg}$ ) for 42 days starting 14 days before fenitrothion were investigated.

Fenitrothion caused early impairment in liver functions accompanied by alteration in serum lipid profile and electrolyte level. Fenitrothion caused an elevation in liver ammonia then serum ammonia then brain ammonia. Both brain and kidney functions were impaired later. Fenitrothion caused a state of oxidative stress in liver, brain and kidney. Prophylaxis with Physalis, Punica or the standard hepatoprotective drug, silymarin largely ameliorated these deleterious effects which might be attributed to their antioxidant properties.

These results suggest that Physalis and Punica might be future candidates for use in the treatment of toxicity by pesticides and further research is required to identify the active ingredients responsible for these protective actions.

Key words: Physalis peruviana, Punica granatum, fenitrothion, Organ, Injury.

\section{INTRODUCTION}

The wide use of pesticides as organophosphrous insecticides (OPIs) causes environmental pollution and potential health hazards. From these hazards, liver disorders are the most common including liver cirrhosis (Prakash and Mullen, 2010). The mechanisms behind OPIs toxic effects include exacerbation of oxidative stress, ammonia production, inhibition of cholinesterases (ChE) with subsequent activation of cholinergic receptors (El-Demerdash, 2011) and alterations in the lipid profile (Lasram et al., 2009). Liver injury associated with organophosphrous insecticides (OPIs) is evidenced by an increase in the enzymatic activity of alanine aminotransferase (ALT), aspartate aminotransferase (AST) and reduced serum albumin level (Celik et al., 2009).

Hepatic injury can be followed by impairment of brain functions or renal functions due to accumulation of various toxic molecules as ammonia which may induce hepatic encephalopathy (HE) and/or hepatorenal syndrome (HRS) (Vaquero et al., 2003). Hepatic encephalopathy, a neuropsychiatric syndrome associated with increased blood and brain ammonia and is characterized by disturbances in mental, emotional and intellectual functions (Ferenci et al., 2002). Oxidative stress is believed to play a role in the pathogenesis of HE because acute doses of ammonia lead to the induction of oxidative stress (Norenberg et al., 2004). 
Hepatorenal syndrome represents a functional reversible renal failure including uremia and chronic kidney disease. It is diagnosed by excluding other causes of renal impairment in patients with hepatic failure, acute and chronic liver disease, and portal hypertension (Schepke, 2007).

Natural dietary antioxidants have important role in healthcare because of their wide biological and medicinal activities, higher safety margins and low costs. Physalis peruviana has hepatoprotective, antioxidant and anti-inflammatory activities as well as anti-proliferative effects on hepatoma cells (Wu et al., 2004). Punica granatum is claimed to have both prophylactic and curative properties against diabetes, cardiovascular diseases, liver damage and aging (Kaur et al., 2006). Silymarin is an antioxidant flavonoid complex derived from the herb milk thistle (Silybum marianum) which is frequently used in the treatment of liver diseases (Mansour et al., 2006).

The aim of the present study is to investigate the possible protective effect of dietary supplement with Physalis, Punica against liver damage induced in rats by fenitrothion (OPIs) in comparison to the standard hepatoprotective silymarin. This study will also investigate the influence of liver injury induced by fenitrothion on brain and kidney functions and whether Physalis, Punica and silymarin would have a protective effect on brain and kidney functions.

\section{MATERIALS and METHODS}

\section{Materials:}

Fenitrothion insecticide (Sumithion $50^{\circledR}$ ) was purchased from Kafr Elzayat Co. for Insecticide Ind., Kafr Elzayat, Egypt. Fenitrothion suspension was freshly prepared by diluting fenitrothion with distilled water to $10 \mathrm{mg} / \mathrm{ml}$ and orally administered in a dose of $10 \mathrm{mg} / \mathrm{kg}$ (Korany and Ezzat, 2011).

Ripe Physalis peruviana fruits (golden berry), family Solanaceae were obtained from local source in Zagazig, Sharkiah, Egypt. The authenticity of the plant species was confirmed by Pharmacognosy Department, Faculty of Pharmacy, Zagazig University. Only fruits at similar ripening stage were selected for processing. Juice was prepared using a commercial blender (Braun, ZK 200, Germany), filtered and pasteurised at $80{ }^{\circ} \mathrm{C}$ for $10 \mathrm{~min}$ to inactivate endogenous enzymes. Small aliquots $(75 \mathrm{ml})$ of juice were stored at $20{ }^{\circ} \mathrm{C}$ for no longer than 2 months. Aliquots were defrosted and immediately mixed with the animal diet at a ratio of $15 \mathrm{~g}$ juice $/ 100 \mathrm{~g}$ food (Ramadan and Moersel, 2007).

Punica granatum (Pomegranate): Ripe Punica granatum fruits, family Punicaceae were obtained from local source in Zagazig, Sharkiah, Egypt. The authenticity of the plant species was confirmed by Pharmacognosy Department, Faculty of Pharmacy, Zagazig University. Pomegranates were washed and manually peeled, without separating the seeds. Juice was prepared using a commercial blender (Braun, ZK 200, Germany), filtered and immediately diluted with distilled water (1:3) and stored at $-20^{\circ} \mathrm{C}$ for no longer than 2 months. Aliquots were defrosted immediately and orally administered in a dose of $3 \mathrm{ml} / \mathrm{kg}$ (Faria et al., 2007).

The aqueous extract of silymarin was provided as a kind gift from MEBACO, Pharmaceutical Company, Cairo, Egypt. Silymarin extract suspension was prepared by suspending $100 \mathrm{mg}$ of silymarin extract in 1 $\mathrm{ml}$ distilled water and orally administered in a dose of $100 \mathrm{mg} / \mathrm{kg}$ (Galal et al., 2012).

\section{Animals}

Male albino rats weighing 150-180 g were obtained from National Research Center, Cairo, Egypt and were housed in plastic cages, allowed free access to a standard diet and tap water. The rats were housed at $23 \pm 2^{\circ} \mathrm{C} 12 \mathrm{hr}$ dark/light cycle. All experimental procedures were approved by the Ethical Committee for Animal Handling at Zagazig University (ECAHZU) (NO: P7-3-2013) and (NO: P8-32013). Animals were sacrificied at the end of 
experiment by decapitation after fasting overnight.

Animals were randomly allocated into one of the following groups $(n=10)$ : control group (oral distilled $\mathrm{H}_{2} \mathrm{O}, 3 \mathrm{ml} / \mathrm{kg} /$ day for 42 day), F1 (oral fenitrothion, $10 \mathrm{mg} / \mathrm{kg} /$ day for 7 days), F2 (oral fenitrothion $10 \mathrm{mg} / \mathrm{kg} /$ day for 14 day), F3 (oral fenitrothion, $10 \mathrm{mg} / \mathrm{kg} /$ day for 21 day), F4 (oral fenitrothion, 10 $\mathrm{mg} / \mathrm{kg} /$ day for 28 day), Phy (oral Physalis juice, $15 \%$ of diet/day for 42 day and fenitrothion, $10 \mathrm{mg} / \mathrm{kg} / \mathrm{day}$ for 28 day starting from day 15 of Physalis administration), Pun (oral Punica juice $3 \mathrm{ml} / \mathrm{kg}$ /day for 42 day and fenitrothion, $10 \mathrm{mg} / \mathrm{kg} /$ day for 28 day starting from day 15 of Punica administration) and Sil (oral silymarin, $100 \mathrm{mg} / \mathrm{kg} /$ day for 42 day and fenitrothion, $10 \mathrm{mg} / \mathrm{kg} / \mathrm{day}$ for 28 day starting from day 15 of silymarin ).

At the end of experiment, after overnight fasting, blood was collected from the retro-orbital plexus vein and centrifuged at $3500 \mathrm{rpm}$ for 15 minutes with or without heparin and serum/plasma was collected and stored at $-20^{\circ} \mathrm{C}$. Animals were sacrificed and liver, brain cortex and kidney were excised for preparation of tissue homogenates.

\section{Methods}

AChE activity in brain was determined colorimetrically (Ellman et al., 1961), amino acid (glutamate and GABA) and monoamine (DA, NE and 5-HT) level in brain cortex were determined fluoremetrically (Harrison et al., 1979; Lowe et al., 1958).

Catalase (CAT) activity, reduced glutathione (GSH) and malondialdhyde (MDA) level in tissue (liver, brain and kidney) were determined colorimetrically (Beutler et al., 1963; Sinha, 1972; Yoshioka et al., 1979).

The following parameters were assayed in serum using kits supplied by Biodiagnostic Co (Cairo, Egypt); ALT activity, ALP activity, Albumin level, Butrylcholiesterase activity, Sodium level, Potassium level, Magnisium level, Cholesterol level, HDLcholesterol level, LDL-cholesterol level, blood urea nitrogen (BUN) level, Creatinine level and Uric acid level. Prothrombin time was determined in plasma using kit supplied by Biodiagnostic Co (Cairo, Egypt). Liver, serum and brain ammonia level was determined by colorimetric method using a kit supplied by Biodiagnostic Co (Cairo, Egypt).

\section{Statistical analysis:}

The results are expressed as means \pm SD. The statistical significance of the data has been determined using one way analysis of variance (ANOVA) followed by LSD and Tukey's post hoc test using SPSS software package version 10 . The level of significance was taken as $\mathrm{P}<0.05$.

\section{RESULTS}

\section{Effect on liver functions}

Administration of fenitrothion for 7 , 14, 21 and 28 days (F1, F2, F3 and F4 respectively), caused a significant increase in serum ALT, ALP activities and prothrombin time compared with control group while, treatment with Physalis, Punica or silymarin for 42 (starting 14 days before fenitrothion) induced a significant decrease in serum ALT, alkaline phosphatase (ALP) activities and prothrombin time compared with F4 group (Table 1).

Table (1) also shows that administration of fenitrothion for 7, 14, 21 and 28 days (F1, F2, F3 and F4, respectively), caused significant reduction in serum albumin level and serum butrylcholine esterase (BuChE) activity compared with control group and treatment with Physalis, Punica or silymarin for 42 days (starting 14 days before fenitrothion) caused a significant increase in serum albumin level and serum BuChE activity compared with F4 group. 
Table (1): Effects of daily oral administration of fenitrothion $(10 \mathrm{mg} / \mathrm{kg}$ ) alone or in combination with Physalisperuviana (15\% of diet), Punicagranatum $(3 \mathrm{ml} / \mathrm{kg})$ or silymarin $(100 \mathrm{mg} / \mathrm{kg})$ on serum ALT, serum ALP, serum Albumin, serum BuChE and Prothrombin time. Data are presented as mean \pm S.D. $(\mathrm{n}=10)$.

\begin{tabular}{|c|c|c|c|c|c|c|c|c|}
\hline \multirow[t]{2}{*}{ Parameter } & Control & F1 & $\mathrm{F} 2$ & F3 & $\mathrm{F} 4$ & Phy & Pun & Sil \\
\hline & \multicolumn{8}{|c|}{ Mean \pm SD } \\
\hline Serum ALT & $41.3 \pm$ & $48.1 \pm 1.1$ & $49.6 \pm$ & $52.1 \pm$ & $56.3 \pm$ & $42.2 \pm$ & $42.6 \pm$ & $40.5 \pm 0.9$ \\
\hline (U/L) & 0.97 & $8^{* \pi \# \in}$ & $1.29^{* \pi \# €}$ & $1.7^{* \text { 『onte }}$ & $0.64 *^{\circledR \infty} \pi €$ & $0.64^{\circledR \infty \pi \#}$ & $0.73^{\circledR \infty \pi \#}$ & $4^{\circledR \infty \pi \#}$ \\
\hline Serum ALP & $112.1 \pm$ & $137.8 \pm$ & $161.8 \pm$ & $199.4 \pm$ & $251.3 \pm$ & $171.2 \pm$ & $112.1 \pm$ & $133.1 \pm 2$ \\
\hline (U/L) & 2.27 & $1.93^{* \infty \pi \#}$ & $2.2^{* \mathbb{B} \pi \# \epsilon}$ & $3.17^{* \text { BळHE }}$ & $3.66^{* \mathbb{B} \infty \pi}$ & $4.24^{* \circledast \infty \pi \# \in}$ & $2.56^{\circledR \infty \pi \# €}$ & $79^{* \infty \pi \#}$ \\
\hline \multirow{2}{*}{$\begin{array}{l}\text { Serum albumin } \\
\qquad(\mathrm{gm} / \mathrm{dl})\end{array}$} & \multirow[t]{2}{*}{$4.8 \pm 0.02$} & $4.1 \pm 0.05$ & $3.7 \pm 0.06$ & $3.6 \pm 0.09$ & $3.1 \pm 0.08$ & $4.4 \pm 0.07$ & $4.3 \pm 0.08$ & $4.2 \pm 0.05$ \\
\hline & & ${ }^{*} \infty \pi \# €$ & *®i $\pi$ \# & * BळotE & $*^{\mathbb{B} \infty} \pi \epsilon$ & ${ }^{*} \mathbb{B} \infty \pi \# €$ & ${ }^{*} \mathbb{B} \infty \pi \#$ & $*_{\circledast} \infty \pi \#$ \\
\hline Serum BuChE & $16380 \pm 2$ & $9696 \pm$ & $8557 \pm$ & $7879 \pm$ & $7544 \pm$ & $15372 \pm$ & $14767 \pm$ & $13973 \pm$ \\
\hline \multirow[t]{2}{*}{ (U/L) } & 25.7 & $125.2^{* \infty}$ & $88.6^{* \circledast \pi \# €}$ & $102.7^{*^{\circledR \infty} €}$ & $83.1^{*^{\circledR \infty} €}$ & $302.4^{* \mathbb{\infty} \infty}$ & $185.3^{* \text { ®ळ }}$ & $45.5^{* \circledR \infty \pi \#}$ \\
\hline & & $\pi \# €$ & & & & $\pi \# €$ & $\pi \# €$ & \\
\hline \multirow{2}{*}{$\begin{array}{l}\text { Prothrombin } \\
\text { time }(\mathrm{Sec})\end{array}$} & \multirow[t]{2}{*}{$16.1 \pm 0.4$} & $16 \pm 0.27^{\#}$ & $16.8 \pm$ & $17.1 \pm$ & $18.2 \pm$ & $16.8 \pm$ & $16.7 \pm$ & $16.7 \pm$ \\
\hline & & $\pi$ & $0.64 *$ & $0.19^{*^{\circledR}}$ & $0.63^{\circledR} \infty \pi \epsilon$ & $0.34^{\#}$ & $0.52^{\#}$ & $0.38^{\#}$ \\
\hline
\end{tabular}

Significantly different from control group,

${ }^{\circledR}$ Significantly different from fenitrothion 1 weeks (F1) group

${ }^{\infty}$ Significantly different from fenitrothion 2 weeks (F2) group

${ }^{\pi}$ Significantly different from fenitrothion 3 weeks (F3) group

${ }^{\#}$ Significantly different from fenitrothion 4 weeks (F4) group

${ }^{€}$ Significantly different from silymarin (Sil) groupat $p<0.05$ using ANOVA followed by LSD and Tukey' Post Hoc test.

\section{Effect on electrolyte}

Administration of fenitrothion for 7 , 14, 21 and 28 days (F1, F2, F3 and F4 respectively), caused significant decrease in serum sodium $\left(\mathrm{Na}^{+}\right)$level by $11,23,30$ and $51 \%$, respectively compared with control group (Figure 1a). On the other hand, treatment with Physalis, Punica or silymarin for 42 days (starting 14 days before fenitrothion) caused a significant increase in serum $\mathrm{Na}^{+}$level by 51,55 and $46 \%$, respectively compared with F4 group (Figure 1a).

Administration of fenitrothion for 7 14, 21 and 28 days (F1, F2, F3 and F4 respectively), induced significant decrease in serum potassium $\left(\mathrm{K}^{+}\right)$level by $2,19,32$ and $59 \%$, respectively compared with control group (Figure 1b). Treatment with Physalis, Punica or silymarin for 42 days (starting 14 days before fenitrothion) induced a significant increase in serum $\mathrm{K}^{+}$level by 68,83 and $87 \%$, respectively compared with F4 group (Figure 1b).

Administration of fenitrothion for 7 , 14, 21 and 28 days (F1, F2, F3 and F4 respectively), caused significant decrease in serum magnesium $\left(\mathrm{Mg}^{+2}\right)$ level by 16, 24, 35 and $42 \%$, respectively compared with control group (Figure 1c). Treatment with Physalis, Punica or silymarin for 42 days (starting 14 days before fenitrothion) caused significant increase in serum $\mathrm{Mg}^{+2}$ level by 48, 51 and $46 \%$, respectively compared with $\mathrm{F} 4$ group (Figure 1c). 


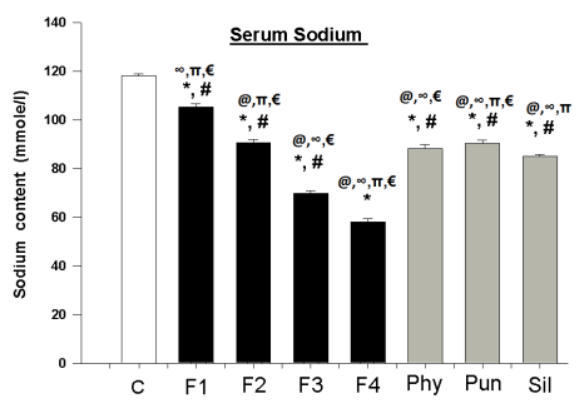

(a)

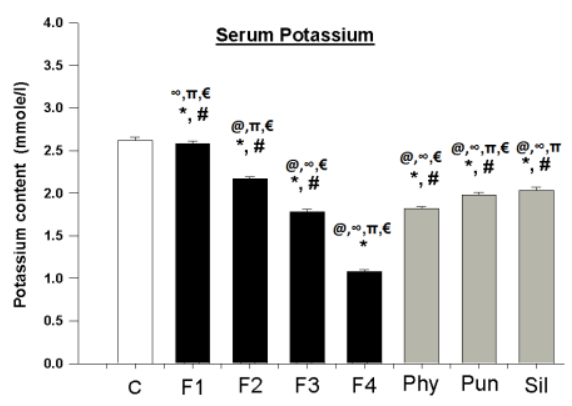

(b)

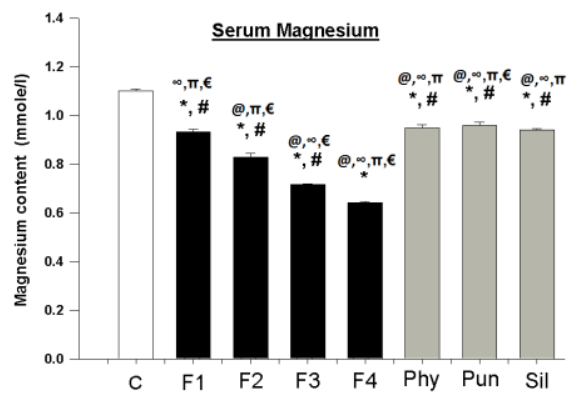

(c)

Figure (1)

Fig.1: Effects of daily oral administration of fenitrothion $(10 \mathrm{mg} / \mathrm{kg})$ alone or in combination with Physalis peruviana (15\% of diet), Punica granatum $(3 \mathrm{ml} / \mathrm{kg})$ or silymarin $(100 \mathrm{mg} / \mathrm{kg})$ on serum: a) Sodium, b) Potassium and c) Magnesium. Data are presented as mean \pm S.D. $(n=10)$.* Significantly different from control group, \# Significantly different from fenitrothion 4 weeks (F4) group at $\mathrm{p}<0.05$ using ANOVA followed by LSD and Tukey' Post Hoc test.

\section{Effect on lipid profile}

Administration of fenitrothion for 14 , 21 and 28 days (F2, F3 and F4, respectively), caused a significant increase in serum cholesterol level by 16,41 and $77 \%$, respectively compared with control group (Figure 2a). On the other hand, treatment with Physalis, Punica or silymarin for 42 days (starting 14 days before fenitrothion) induced a significant decrease in serum cholesterol level by 80,74 and $84 \%$, respectively compared with F4 group (Figure 2a).

Administration of fenitrothion for 7 , 14, 21 and 28 days (F1, F2, F3 and F4, respectively), caused a significant increase in serum LDL level by 24, 68, 118 and $131 \%$, respectively compared with control group (Figure 2b). Treatment with Physalis, Punica or silymarin for 42 days (starting 14 days before fenitrothion) caused a significant decrease in serum LDL level by 40, 48 and 30 $\%$, respectively compared with $\mathrm{F} 4$ group (Figure 2b).

Administration of fenitrothion for 14 , 21 and 28 days (F2, F3 and F4 respectively), caused a significant reduction in serum HDL level by 19,39 and $57 \%$, respectively compared with control group (Figure 2c). Treatment with Physalis, Punica or silymarin for 42 days (starting 14 days before fenitrothion) caused a significant elevation in serum HDL level by 103, 103 and $102 \%$, respectively compared with F4 group (Figure 2c).

\section{Effect on ammonia}

Administration of fenitrothion for 7 , 14, 21 and 28 days (F1, F2, F3 and F4) respectively), caused a significant increase in liver ammonia level by 26, 71, 129 and $214 \%$ respectively, compared with control group (Figure 3a). Additionally, treatment with Physalis, Punica or silymarin for 42 days (starting 14 days before fenitrothin) caused a significant decrease in liver ammonia level by 48,50 and $49 \%$, respectively compared with F4 group (Figure 3a). 


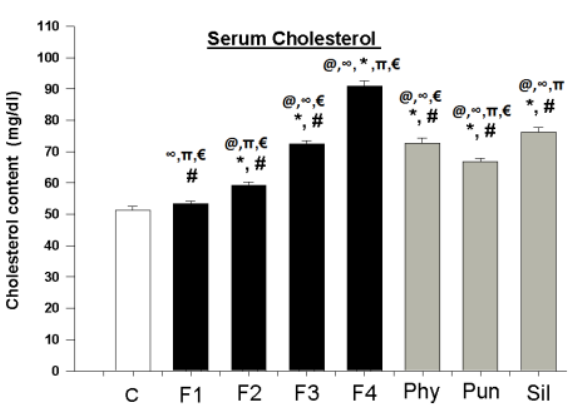

(a)

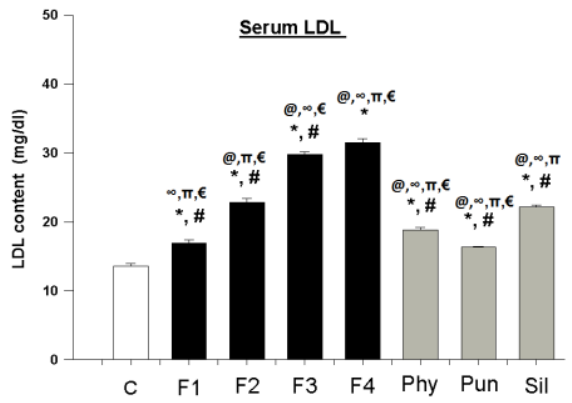

(b)

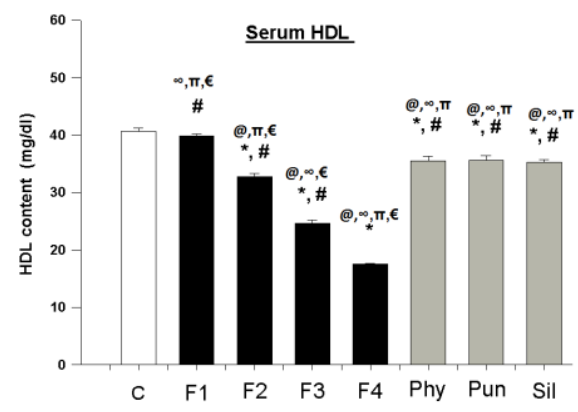

(c)

Figure (2)

Fig.2: Effects of daily oral administration of fenitrothion $(10 \mathrm{mg} / \mathrm{kg})$ alone or in combination with Physalis peruviana (15\% of diet), Punica granatum (3 $\mathrm{ml} / \mathrm{kg})$ or silymarin (100 $\mathrm{mg} / \mathrm{kg})$ on serum: a) Cholesterol, b) LDL and c) HDL. Data are presented as mean \pm S.D. $(n=10)$. * Significantly different from control group, \# Significantly different from fenitrothion 4 weeks (F4) group at $\mathrm{p}<0.05$ using ANOVA followed by LSD and Tukey' Post Hoc test.
Administration of fenitrothion for 14 , 21 and 28 days (F2, F3 and F4 respectively), caused a significant increase in serum ammonia level by 16, 65 and $116 \%$, respectively compared with control group (Figure 3b). On the other hand, treatment with Physalis, Punica or silymarin for 42 days (starting 14 days before fenitrothion) caused a significant decrease in serum ammonia level by 46,36 and $37 \%$, respectively compared with F4 group (Figure 3b).

Administration of fenitrothion for 14, 21 and 28 days (F2, F3 and F4, respectively), caused a significant increase in brain ammonia level in cerebral cortex by 15, 30 and $53 \%$, respectively compared with control group (Figure 3c). Meanwhile, treatment with Physalis, Punica or silymarin for 42 days (starting 14 days before fenitrothion) caused a significant decrease in brain ammonia in cerebral cortex by 26, 25 and $25 \%$, respectively compared with $\mathrm{F} 4$ group (Figure 3c).

\section{Effect on brain neurotransmitters}

Administration of fenitrothion for 7 , 14, 21 and 28 days (F1, F2, F3 and F4, respectively), caused a significant decrease in brain cortex acetylcholine esterase (AChE) activity, norepinephrine (NE) level and dopamine (DA) level compared with control group, while, treatment with Physalis, Punica or silymarin for 42 days (starting 14 days before fenitrothion) caused a significant increase in AChE activity, NE level and DA level in cerebral cortex compared with F4 group. On the other hand, administration of fenitrothion for 14, 21 and 28 days (F2, F3 and $F 4$, respectively), caused significant elevation in brain cortex level of glutamate, gamma aminobutric acid (GABA) and 5hydroxytryptamine (5-HT) compared with control group. Additionally, treatment with Physalis, Punica or silymarin for 42 days (starting 14 days before fenitrothion) caused a significant reduction in brain cortex level of glutamate, GABA and 5-HT compared with F4 group (Table 2). 
Table (2): Effects of daily oral administration of fenitrothion $(10 \mathrm{mg} / \mathrm{kg}$ ) alone or in combination with Physalisperuviana (15\% of diet), Punicagranatum $(3 \mathrm{ml} / \mathrm{kg}$ ) or silymarin $(100 \mathrm{mg} / \mathrm{kg})$ on brain acetylcholine esterase (AChE), glutamate, norepinephrine (NE), dopamine (DA), gamma amino butyric acid (GABA) and serotonine (5hydroxytryptamine, 5-HT).

\begin{tabular}{|c|c|c|c|c|c|c|c|c|}
\hline $\begin{array}{l}\text { Brain Content } \\
\text { (per gram) }\end{array}$ & $\begin{array}{c}\text { control } \\
\text { mean } \pm \\
\text { SD }\end{array}$ & $\begin{array}{c}\mathrm{F} 1 \\
\text { mean } \pm \mathrm{SD}\end{array}$ & $\begin{array}{c}\mathrm{F} 2 \\
\text { mean } \pm \mathrm{SD}\end{array}$ & $\begin{array}{c}\mathrm{F} 3 \\
\text { mean } \pm \mathrm{SD}\end{array}$ & $\begin{array}{c}\mathrm{F} 4 \\
\text { mean } \pm \mathrm{SD}\end{array}$ & $\begin{array}{c}\text { Phy } \\
\text { mean } \pm \text { SD }\end{array}$ & $\begin{array}{c}\text { Pun } \\
\text { mean } \pm \\
\text { SD }\end{array}$ & $\begin{array}{c}\text { Sil } \\
\text { mean } \pm \text { SD }\end{array}$ \\
\hline $\begin{array}{c}\mathrm{AChE} \\
(\mu \mathrm{mole} / \mathrm{min}\end{array}$ & $\begin{array}{c}0.464 \pm \\
0.009\end{array}$ & $\begin{array}{c}0.439 \pm 0.0 \\
04^{* \infty} \pi \| \epsilon \in\end{array}$ & $\begin{array}{c}0.399 \pm \\
0.002^{* \circledast \pi \pi t \in}\end{array}$ & $\begin{array}{c}0.324 \pm 0.0 \\
06^{* \text { ®øotte }}\end{array}$ & $\begin{array}{c}0.207 \pm 0.0 \\
03^{* \otimes \infty} \pi €\end{array}$ & $\begin{array}{c}0.416 \pm 0.0 \\
04^{* \otimes \infty \pi t Æ \epsilon}\end{array}$ & $\begin{array}{l}0.413 \pm 0.0 \\
06^{* \mathbb{B} \infty \pi t \sharp}\end{array}$ & $\begin{array}{c}0.373 \pm 0.0 \\
07^{* \circledR \infty} \pi^{* \#}\end{array}$ \\
\hline $\begin{array}{c}\text { glutamate } \\
(\mu \text { mole })\end{array}$ & $\begin{array}{c}20.2 \pm \\
0.4\end{array}$ & $\begin{array}{c}21.03 \pm 0.2 \\
9^{\# \infty \pi} \pi\end{array}$ & $23.3 \pm 0.4^{*}$ & 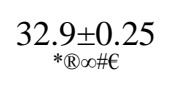 & $45.1 \pm 0.53$ & $2 \underset{* \mathbb{B} \infty \pi \#}{25.2 \pm 0.18}$ & $25.1 \pm 0.24$ & $24.9 \pm 0.34$ \\
\hline $\mathrm{NE}(\mu \mathrm{g})$ & $\begin{array}{c}18.3 \pm \\
0.13\end{array}$ & $\begin{array}{c}18.87 \pm 0.0 \\
9^{\infty \pi \# €}\end{array}$ & $\underset{\pi \# \in}{16 \pm 0.08^{*(\circledast)}}$ & $12.4 \pm 0.09$ & $8.5 \pm 0.17^{*}$ & $15.1 \pm 0.16$ & $14 \underset{* \otimes \infty \pi}{14.8 \pm 0.08}$ & $14.3 \pm 0.22$ \\
\hline $\mathrm{DA}(\mu \mathrm{g})$ & $\begin{array}{c}91.7 \pm \\
0.89\end{array}$ & $\begin{array}{c}91.07 \pm 0.5 \\
3^{\infty \pi \# €}\end{array}$ & 69.9 $9 \pm 1.41$ & $59.7 \pm 0.73$ & $50.1 \pm 0.75$ & $\begin{array}{c}77.4 \pm 0.23 \\
{ }^{*} \mathbb{\infty} \infty \pi \notin \in\end{array}$ & $\begin{array}{c}76.9 \pm 0.54 \\
*{ }^{*} \infty \infty \pi \# \in\end{array}$ & $74 \underset{* \circledast \infty \pi \#}{2.2 \pm 1.21}$ \\
\hline $\begin{array}{l}\text { GABA } \\
(\mu \text { mole })\end{array}$ & $\begin{array}{c}18.3 \pm \\
0.13\end{array}$ & $\begin{array}{c}18.87 \pm 0.0 \\
9^{\infty \pi \# \in \in}\end{array}$ & $20.2 \pm 0.08$ & $23.8 \pm 0.1^{*}$ & $30.5 \pm 0.24$ & $20.1 \pm 0.28$ & $19.8 \pm 0.14$ & $\underset{* \mathbb{B} \infty \pi \#}{19.6 \pm 0.31}$ \\
\hline $5-\mathrm{HT}(\mu \mathrm{g})$ & $\begin{array}{c}359 \pm 5.6 \\
5\end{array}$ & $\frac{367 \pm 3.99^{\infty}}{\pi \# \in}$ & $\underset{\mathbb{B} \pi \# \in \in}{427 \pm 3.16^{*}}$ & $\underset{\text { Boofte }}{527 \pm 8.51^{*}}$ & $\underset{\mathbb{B} \infty \pi \in}{627 \pm 9.73^{*}}$ & $4 \underset{\mathbb{B} \infty \pi \#}{466 \pm 4.24^{*}}$ & $4 \underset{\mathbb{B} \infty \pi \#}{462 \pm 3.63^{*}}$ & $\underset{\mathbb{B} \infty \pi \#}{458 \pm 4.51^{*}}$ \\
\hline
\end{tabular}

"Significantly different from control group,

${ }^{\circledR}$ Significantly different from fenitrothion 1 weeks (F1) group

${ }^{\infty}$ Significantly different from fenitrothion 2 weeks (F2) group

${ }^{\pi}$ Significantly different from fenitrothion 3 weeks (F3) group

${ }^{\#}$ Significantly different from fenitrothion 4 weeks (F4) group

${ }^{€}$ Significantly different from silymarin (Sil) groupat $p<0.05$ using ANOVA followed by LSD and Tukey' Post Hoc test.

\section{Effect on kidney function}

Administration of fenitrothion for 21 and 28 days (F3 and F4 respectively), caused a significant increase in serum urea level by 48 and $69 \%$, respectively compared with control group (Figure 4a). Treatment with Physalis, Punica or silymarin for 42 days (starting 14 days before fenitrothion) caused a significant decrease in serum urea level by 40,35 and $41 \%$, respectively compared with $\mathrm{F} 4$ group (Figure 4a).

Administration of fenitrothion for 21 and 28 days (F3 and $\mathrm{F} 4$ respectively), caused a significant increase in serum creatinine level by 25 and $62.5 \%$, respectively compared with control group (Figure 4b). Additionally, treatment with Physalis, Punica or silymarin for 42 days (starting 14 days before fenitrothion) caused a significant decrease in serum creatinine level by 22, 17 and 16\%, respectively compared with F4 group (Figure 4b ).

Administration of fenitrothion for 14, 21 and 28 days (F2, F3 and F4 respectively), caused a significant increase in serum uric acid level by 24, 54 and $76 \%$, respectively compared with control group (Figure 4c). Treatment with Physalis, Punica or silymarin for 42 days (starting 14 days before fenitrothion) induced a significant decrease in serum uric acid level by 34, 32 and $37 \%$, respectively compared with F4 group (Figure 4c).

\section{Effect on oxidative stress biomarkers}

Administration of fenitrothion for 7 days (F1) caused a significant initial increase in catalase (CAT) activity and glutathione 


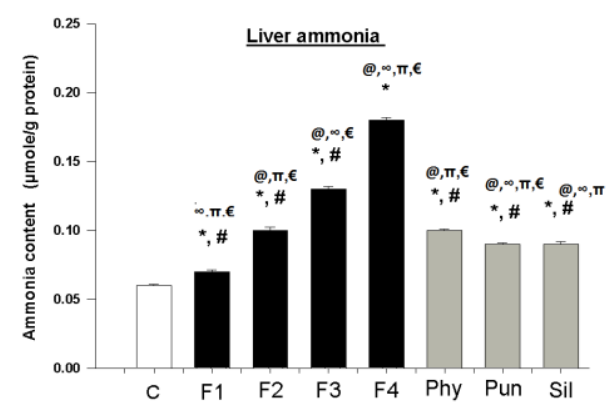

(a)

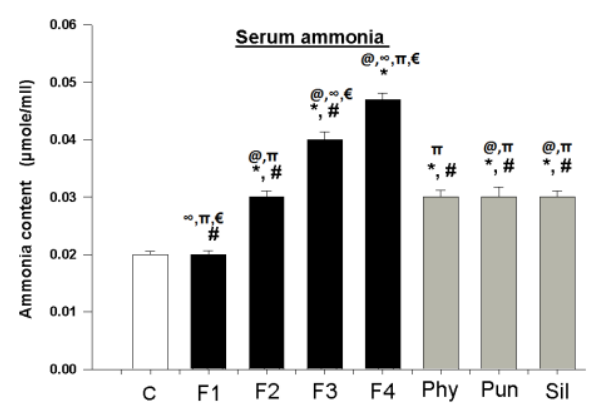

(b)

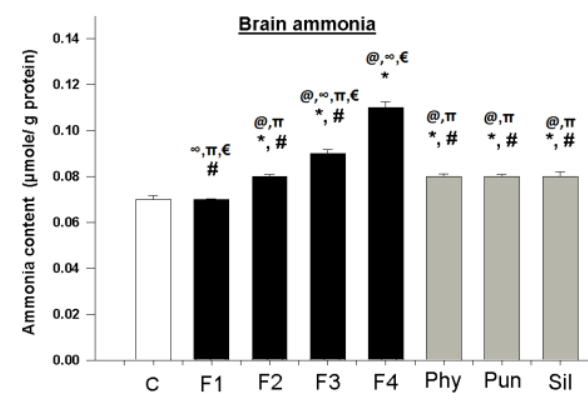

(c)

Figure (3)

Fig.3: Effects of daily oral administration of fenitrothion $(10 \mathrm{mg} / \mathrm{kg})$ alone or in combination with Physalis peruviana (15\% of diet), Punica granatum $(3 \mathrm{ml} / \mathrm{kg})$ or silymarin $(100 \mathrm{mg} / \mathrm{kg})$ on ammonia level in: a) liver, b) serum and c) brain. Data are presented as mean \pm S.D. $(\mathrm{n}=10)$. * Significantly different from control group, \# Significantly different from fenitrothion 4 weeks (F4) group at $\mathrm{p}<0.05$ using ANOVA followed by LSD and Tukey' Post Hoc test.

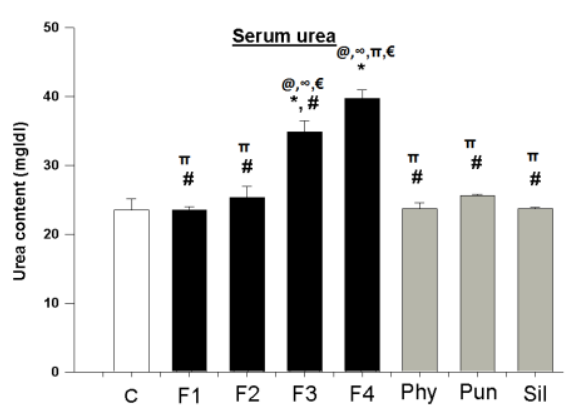

(a)

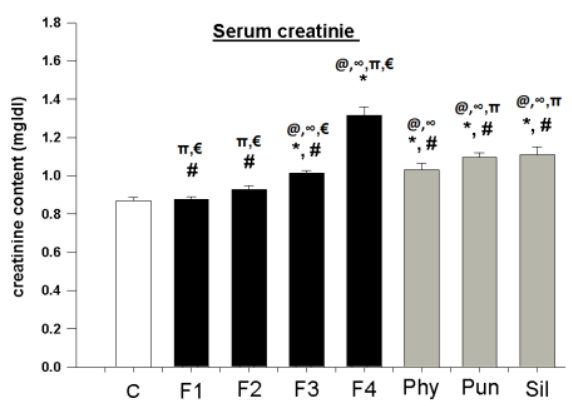

(b)

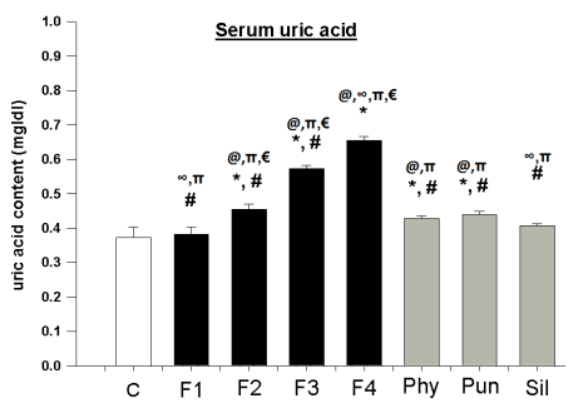

(c)

Figure (4)

Fig.4: Effects of daily oral administration of fenitrothion $(10 \mathrm{mg} / \mathrm{kg})$ alone or in combination with Physalis peruviana (15\% of diet), Punica granatum (3 $\mathrm{ml} / \mathrm{kg})$ or silymarin $(100 \mathrm{mg} / \mathrm{kg})$ on serum: a) urea, b) creatinine and c) uric acid. Data are presented as mean \pm S.D. $(\mathrm{n}=10)$. * Significantly different from control group, \# Significantly different from fenitrothion 4 weeks (F4) group at $\mathrm{p}<0.05$ using ANOVA followed by LSD and Tukey' Post Hoc test. 
(GSH) level in liver, brain and kidney compared with control group, however, continued administration of fenitrothion lead to a decrease in catalase (CAT) activity and glutathione (GSH) level in liver, brain and kidney compared with control group. On the other hand, administration of fenitrothion for 7 days (F1) caused a significant initial decrease in malodialdhyde (MDA) level in liver, brain and kidney compared with control group, however, continued administration of fenitrothion lead to an increase in malodialdhyde (MDA) level in liver, brain and kidney compared with control group (Table 3).

Treatment with Physalis, Punica or silymarin for 42 days (starting 14 days before fenitrothion) caused a significant increase in liver, brain and kidney catalase activity and glutathione (GSH) level while liver, brain and kidney malodialdhyde (MDA) level was significantly reduced (Table 3 ).

Table (3): Effects of daily oral administration of fenitrothion $(10 \mathrm{mg} / \mathrm{kg}$ ) alone or in combination with Physalisperuviana $(15 \%$ of diet), Punicagranatum $(3 \mathrm{ml} / \mathrm{kg})$ or silymarin $(100 \mathrm{mg} / \mathrm{kg})$ on: catalase, glutathione and malondaldahyde in liver, brain and kidney. Data are presented as mean \pm S.D. $(n=10)$.

\begin{tabular}{|c|c|c|c|c|c|c|c|c|}
\hline Parameters & $\begin{array}{c}\text { Control } \\
\text { mean } \pm \text { SD }\end{array}$ & $\begin{array}{c}\mathrm{F} 1 \\
\text { mean } \pm \mathrm{SD}\end{array}$ & $\begin{array}{c}\mathrm{F} 2 \\
\text { mean } \pm \mathrm{SD}\end{array}$ & $\begin{array}{c}\mathrm{F} 3 \\
\text { mean } \pm \mathrm{SD}\end{array}$ & $\begin{array}{c}\mathrm{F} 4 \\
\text { mean } \pm \mathrm{SD}\end{array}$ & $\begin{array}{c}\text { Phy } \\
\text { mean } \pm \text { SD }\end{array}$ & $\begin{array}{c}\text { Pun } \\
\text { mean } \pm \text { SD }\end{array}$ & $\begin{array}{c}\text { Sil } \\
\text { mean } \pm \text { SD }\end{array}$ \\
\hline $\begin{array}{l}\text { Liver CAT } \\
(\mu \mathrm{mole} \\
/ \mathrm{min} / \mathrm{mg})\end{array}$ & $\begin{array}{c}0.069 \pm \\
0.002\end{array}$ & $\begin{array}{c}0.085 \pm 0.0 \\
01^{* \infty \pi \# €}\end{array}$ & $\begin{array}{c}0.066 \pm 0.0 \\
01^{\circledR \pi} \pi €\end{array}$ & $\begin{array}{c}0.06 \pm 0.00 \\
1^{* \mathbb{R} \infty \# €}\end{array}$ & $\begin{array}{c}0.048 \pm 0.0 \\
01^{* \circledR \infty \pi}\end{array}$ & $\begin{array}{c}0.089 \pm 0.0 \\
02^{* \infty \pi \# €}\end{array}$ & $\begin{array}{c}0.09 \pm 0.00 \\
2^{* \infty \pi \# €}\end{array}$ & $\begin{array}{c}0.081 \pm 0.0 \\
01^{* \mathbb{\infty} \pi \#}\end{array}$ \\
\hline $\begin{array}{l}\text { Liver GSH } \\
(\mathrm{mg} / \mathrm{g})\end{array}$ & $2.8 \pm 0.05$ & $\underset{\infty \pi \#}{3.2 \pm 0.05^{*}}$ & $2.97 \pm 0.03$ & $2.7 \pm 0.06^{*}$ & $2.4 \pm 0.06^{*}$ & $3.05 \pm 0.05$ & $3.1 \pm 0.05^{*}$ & $3.1 \pm 0.07^{*}$ \\
\hline $\begin{array}{c}\text { Liver MDA } \\
(\mu \text { mole/g) }\end{array}$ & $5.2 \pm 0.1$ & $\underset{\infty \pi \# \in}{4.1 \pm 0.06^{*}}$ & $6.8 \underset{\circledast \pi \#}{ \pm 0.14^{*}}$ & 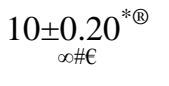 & $13.6 \pm 0.25$ & $\underset{B \infty \pi \#}{7.2 \pm 0.15^{*}}$ & $\underset{\pi \#}{6.6 \pm 0.1^{* ®}}$ & $\underset{\circledR \pi \#}{6.9 \pm 0.06^{*}}$ \\
\hline $\begin{array}{l}\text { Brain CAT } \\
\quad(\mu \mathrm{mole} \\
/ \mathrm{min} / \mathrm{mg})\end{array}$ & $\begin{array}{c}0.34 \pm 0.00 \\
8\end{array}$ & $0.37 \pm 0^{* \infty \pi}$ & $\begin{array}{c}0.34 \pm 0.00 \\
2^{\circledR \pi \#}\end{array}$ & $\begin{array}{c}0.29 \pm 0.00 \\
2^{* \mathbb{B} \infty \# €}\end{array}$ & $\begin{array}{c}0.24 \pm 0.00 \\
5^{* ® \infty} \pi €\end{array}$ & $0.34 \pm 0^{\mathbb{B} \# \pi}$ & $0.35 \pm 0_{\pi €}^{\circledR \#}$ & $0.33 \pm 0^{\mathbb{B} \# \pi}$ \\
\hline $\begin{array}{c}\text { Brain GSH } \\
(\mathrm{mg} / \mathrm{g})\end{array}$ & $1.34 \pm 0.01$ & $\begin{array}{c}1.57 \pm 0.04 \\
*_{\infty} \pi \# €\end{array}$ & $1.33_{\circledast \pi \#}^{ \pm 0} \pm 0.02$ & $1.1 \pm 0.01^{*} \infty \# €$ & $1 \pm 0.01_{\pi €}^{* \circledR \infty}$ & $1.3 \pm 0.01^{*}$ & $1.35 \underset{* \mathbb{B} \pi \#}{35}$ & $1.3 \underset{\circledR}{ \pm \pi \#}$ \\
\hline $\begin{array}{c}\text { Brain MDA } \\
(\mu \text { mole/g })\end{array}$ & $2.7 \pm 0.06$ & $\underset{\infty \pi \# \in}{2.5 \pm 0.01^{*}}$ & $4 . \underbrace{}_{\mathbb{B} \pi} \pm 0.07^{*}$ & $5.1 \underset{\circledR \infty .07^{*}}{ \pm 0}$ & $\underset{\mathbb{B} \infty \infty \pi €}{5.7 \pm 0.06^{*}}$ & $2.9 \pm 0.02^{*}$ & $\underset{\infty \pi \# €}{2.6 \pm 0.04^{\circledR}}$ & $2.8 \underset{\infty \pi \#}{ \pm 0.07^{\circledR}}$ \\
\hline $\begin{array}{l}\text { Kidney CAT } \\
\quad(\mu \text { mole } \\
/ \mathrm{min} / \mathrm{mg})\end{array}$ & $\begin{array}{c}0.053 \pm 0.0 \\
02\end{array}$ & $\begin{array}{c}0.06 \pm 0.00 \\
3^{* \infty \pi \#}\end{array}$ & $\begin{array}{c}0.054 \pm 0.0 \\
01^{\circledR \# €}\end{array}$ & $\begin{array}{c}0.048 \pm 0.0 \\
02^{* \mathbb{B} \#}\end{array}$ & $\begin{array}{c}0.041 \pm 0.0 \\
03^{* \circledR \infty \pi \epsilon}\end{array}$ & $\underset{\pi \#}{0.055 \pm 0^{* \infty}}$ & $\begin{array}{c}0.062 \pm 0.0 \\
01^{* \infty \pi \#}\end{array}$ & $\begin{array}{c}0.06 \pm 0.00 \\
1^{* \infty \pi \#}\end{array}$ \\
\hline $\begin{array}{l}\text { Kidney GSH } \\
\text { (mg/g) }\end{array}$ & $1.7 \pm 0.11$ & $\begin{array}{c}2.02 \pm 0.11 \\
*_{\infty} \pi \# €\end{array}$ & $1.6 \underset{\otimes \pi \#}{ \pm 0.09}$ & $\underset{\mathbb{B} \infty \ldots €}{1.4 \pm 0.08^{*}}$ & $1.3 \underset{\circledR \infty .06^{*}}{ \pm}$ & $\underset{\pi \#}{1.7 \pm 0.07^{\circledR}}$ & $\underset{\pi \#}{1.7 \pm 0.04^{\circledR}}$ & $\underset{\pi \#}{1.7 \pm 0.04^{\circledR}}$ \\
\hline $\begin{array}{c}\text { Kidney MDA } \\
(\mu \text { mole } / g)\end{array}$ & $5.7 \pm 0.21$ & $\underset{\infty \pi \# €}{5.4 \pm 0.11^{*}}$ & $\begin{array}{c}7.04 \pm 0.18 \\
*_{\circledast} \pi \# \in\end{array}$ & $\underset{\mathbb{B} \infty \# €}{8.8 \pm 0.18^{*}}$ & $11.3 \pm 0.21$ & $\underset{\mathbb{B} \infty \pi \#}{6.2 \pm 0.16^{*}}$ & $6 . \underset{\circledR \infty \pi \#}{2 \pm 0.14^{*}}$ & $6 . \underbrace{}_{\circledR \infty \pi \#} \pm 0.06^{*}$ \\
\hline
\end{tabular}

* Significantly different from control group,

${ }^{\circledR}$ Significantly different from fenitrothion 1 weeks (F1) group

${ }^{\infty}$ Significantly different from fenitrothion 2 weeks (F2) group

${ }^{\pi}$ Significantly different from fenitrothion 3 weeks (F3) group

${ }^{\#}$ Significantly different from fenitrothion 4 weeks (F4) group

${ }^{€}$ Significantly different from silymarin (Sil) groupat $\mathrm{p}<0.05$ using ANOVA followed by LSD and Tukey' Post Hoc test.

\section{DISCUSSION}

The present study was designed to investigate the hepatotoxic effect of fenitrothion as well as the hepatoprotective potential of Physalis and Punica in rats. In addition this study tried to find out whether fenitrothion directly affects the kidney and brain or its hepatotoxic effect has a distant damaging effect on brain and kidney functions. 
Exposure to pesticides is among the most serious health problems in the world (Lasram et al., 2009). Previous studies have shown that exposure to pesticides caused hepatotoxicity (Kalender et al., 2010), hematotoxicity (Durak et al., 2009), genotoxicity (Giri et al., 2002). In addition, OPIs can alter antioxidant enzyme activities and increase the production of free radicals in different tissues including the liver (Kumar et al., 1993); (Hazarika et al., 2003), brain (Kumar et al., 1993); (Brocardo et al., 2005) and kidney (Kumar et al., 1993); (Possamai et al., 2007).

The present study showed that fenitrothion caused liver injury and deterioration in liver function as evidenced by a increase in ALT, ALP activities and prothrombine time and decrease in albumin level and BuChE activity. This alteration in liver function might be attributed to hepatocellular damage and alteration in the permeability of cell membrane (Ncibi et al., 2008); (Ogutcu et al., 2008). Additionally, reduction in albumin level may reflect disturbed amino acid metabolism induced by reactive oxygen species (ROS) generated by OPIs as previously described by Yousef et al., (2006). Furthermore, reduction of $\mathrm{BuChE}$ activity is a consequence of direct inhibtion of cholinesterases by fenitrothion, BuChE is similar to neuronal acetylcholineesterase but found primarily in the liver. Assay of BuChE activity in plasma can be used as a liver function test (Hillman, 1994); (Franco et al., 2009).

In this study, fenitrothion administration caused a significant decrease in serum sodium, potassium and magnesium which indicates a state of liver damage and cirrhosis (Wong and Blendis, 1994). Numerous previous studies have reported that alterations in the levels of minerals may contribute to the pathogenesis of hepatic impairement as hyponatremia (Borroni et al., 2000); (Castello et al., 2005), hypokalemia (Pitts and Van Thiel, 1986) and hypomagnesemia (George, 2006) have been shown in patients with liver cirrhosis

Results of the current study showed increase in cholesterol and LDL and decrease in HDL in serum after administration of fenitrothion. This result is in accordance with those reported by Kalender et al., (2010) who related these alterations in lipid profile to the effect of fentrothion on the blockage of the bile duct, which reduces or stops cholesterol secretion into the duedonum.

Ammonia, one of the principal products of nitrogen metabolism, is normally converted to urea in the liver by a series of enzymatic reactions (Larsen et al., 2001). Liver impairment may cause elevation in blood ammonia concentration, therefore, ammonia level is used widely in the diagnosis of hepatic encephalopathy in cirrhotic patients with altered mental status (Albrecht and Jones, 1999; Jalan et al., 2003).

One important finding of this study was the gradual elevation in liver ammonia starting in the first week, of fenitrothion administration while, significant increase in serum ammonia started in the second week and a significant increase in brain ammonia level started in the third week. These results imply that the damage which started in the liver was followed by blood then brain. These results are in agreement with those reported by Subash and Subramanian, (2008), who reported a significant increase in blood ammonia in Ammonium chloride -induced liver damage in rats. Excess ammonia in blood can cross the blood brain barrier (BBB) causing hepatic encephalopathy (Bosoi et al., 2012) through several mechanisms including, free radical production, changes in lipid composition in brain due to alteration in lipid profile, increased $\mathrm{BBB}$ permeability, brain edema and imbalance between excitatory and inhibitory neurotransmitters (Swapna et al., 2006). Ammonia was also shown to impair brain energy metabolism and autoregulation of blood flow (Larsen et al., 2001). 
In the present study, a gradual increase in brain glutamate, GABA and 5-HT level was observed after fenitrothion administration. While, a gradual decrease in NE and DA level was observed after fenitrothion administration in brain. These results are in agreement with those reported by Jalan et al., (2003) who reported the changes of brain neurotransmitters after liver injury.

The state of hyperammonemia was previously shown to induce changes in GABAergic tone due to modulation by central and peripheral benzodiazepine receptors (Desjardins et al., 1997), while, changes in glutamatergic, dopaminergic and cholinergic system were caused by disturbances in the synthesis and degradation of the amino acids (Hertz et al., 2000); (Sonnewald et al., 1996), and amino acid efflux from and/or reuptake by astrocytes (Zielinska et al., 2002).

The present study, demonstrated inhibition in brain AChE after the first week of administration of fenitrothion. Inhibition of AChE enzyme causes an increase in ACh level at causing neuronal excitation then paralysis of the cholinergic transmission (Bartling et al., 2007).

Hepatorenal syndrome (HRS) is the development of renal failure in patients with severe liver disease in the absence of any other identifiable cause. Prevention of hepatorenal syndrome is frequently neglected in clinical practice (McCormick and Donnelly, 2008). This study showed gradual decline in kidney function evidenced by elevation in blood urea nitrogen (BUN), serum creatinine and serum uric acid starting in the third week after fenitrothion administration. These results coincide with previous studies (Al-Attar, 2010).

Oxidative stress is a major mechanism in the pathophysiology of several diseases including a variety of liver disorders (Medina and Moreno-Otero, 2005). In this study, an initial increase in antioxidant status in liver, brain and kidney was noticed as evidenced by the initial increase in catalase activity, glutathione level and the decrease in malodialdehyde level which was reversed with continued administration of fenitrothion indicating an initial attempt of the body to combate the oxidative stress state induced by fenitrothion which failed and resulted in an evident state of oxidative stress in liver, brain and kidney. Similar effects of OPIs were previously reported (Prasanthi et al., 2005).

The previous results imply that liver damage was the first to occur as it is the first organ to encounter any exogenously administered substance and was confirmed by disturbance in liver function from the first week of exposure. Repeated/continued exposure to the pesticide resulted in a disturbance in the brain and kidney functions starting from the 3rd week and peaked at the 4th week.

This might be a delayed or cumulative effect of the pesticide or due to a cross talk between the liver and other organs mediated mainly by; elevation of the level of toxic byproducts as ammonia that can reach the brain causing neurotoxicity, electrolyte disturbances that might alter the renal hemodynamics causing nephrotoxicity, a state of hepatic oxidative stress that spreads to other organs as the brain and kidney, the brain is the most sensitive organ to the oxidative stress induced either directly due to exposure to pesticides or indirectly due to liver damage and alteration of lipids (profile or generalized alteration of lipid membranes in all body organs).

Recent research has shown that fresh Physalis juice contains (70mg/100ml) polyphenols and high level of flavonoids which have antioxidant actions (Coskun et al., 2005). Fresh Punica juice is rich in polyphenolic compounds (Lansky, 2006; Seeram et al., 2005) which were linked to prevention of cardiovascular diseases, cancer and neurological damage (Lansky and Newman, 2007). Similarly, flavonoids and polyphenolic compounds present in silymarin 
have been shown to possess antioxidant and anti-inflammatory properties (Shaker et al., 2010).

The current study has shown a hepatoprotective effect of Physalis juice which was evidenced by restoration of ALT, ALP, albumin, prothrombin time and $\mathrm{BuChE}$ to near normal values. A similar hepatoprotective effect of Physalis was previously reported by (Arun and Asha, 2007; $\mathrm{Wu}$ et al., 2004) who suggested that the reversal of increased serum enzymes in rats fed by Physalis was due to the prevention of the leakage of intracellular enzymes by its membrane stabilizing activity. Similar hepatoprotective effect was observed in punica-treated rats as evidenced by normalization of liver function parameters including ALT, ALP, albumin, prothrombin time and BuChE which were altered by fenitrothion. This might be attributed to the ability of Punica to scavenge free radicals due to polyphenol and flavonoid level, thus preventing hepatocellular damage, thereby preserving the structural integrity of cell and suppressing the leakage of enzymes through plasma membranes (Toklu et al., 2007). In the present study, pretreatment with silymarin confirmed its hepatoprotective effect (Pradeep et al., 2007) on ALT, ALP, albumin, prothrombin time and $\mathrm{BuChE}$.

The present study showed that administration of physalis, physalis and silymarin caused an increase in serum sodium, potassium and magnesium. These effects may be due to the high level of minerals (Ross and Desai, 2005) and/or flavonoid level (Wang et al., 2000).

Results of the current study showed a decrease in cholesterol and LDL and an increase in HDL in serum after administration of Physalis, Punica and silymarin. Punica juice was previously reported to reduce cholesterol oxidation and reduce the retention of LDL (Singh et al., 2002) while, Punica was reported to decrease total lipids and total cholesterol in albino rats subjected to $\mathrm{CCl}_{4}$ toxicity and silymarin was shown to reduce cholesterol synthesis (Nassuato et al., 1991) in rats.

Wasan et al., have related the decrease of TC and LDL-cholesterol with an increase in HDL-cholesterol level to the wealth of phytosterols which are known to decrease in cholesterol solubility and absorption across the intestinal barrier and consequently decreasing cholesterol level in plasma (Wasan et al., 2001). In addition, flavonoids were reported to inhibit LDL oxidation and platelet aggregation thus leading to reduced LDL and cholesterol levels (Kurowska et al., 2000). In addition, (Basu and Penugonda, 2009) suggested that the principal mechanisms of action of Punica juice as anti-atherogenic may be due to its potent antioxidative capacity.

In the present study, administration of Physalis, Punica and silymarin with fenitrothion normalized the alteration in ammonia level in liver, serum and brain. The current finding supports those obtained by (Subash and Subramanian, 2009) who reported that administration of morin (a flavonoid) decreased the levels of blood ammonia and urea in rats with ammonium chloride induced hyperammonemia.

In the present study, administration of Physalis, Punica and silymarin with fenitrothion ameliorated the disturbed in neurotransmitters induced by fenitrothion. This may be a local direct antioxidant action of flavonoid present in these plants in the brain as previously described (Youdim et al., 2004); (Jager and Saaby, 2011) or an indirect effect due to their hepatoprotective effect and prevention of excessive ammonia formation (Subash and Subramanian, 2008).

The present study showed that administration of Punica, Physalis and silymarin had a nephroprotective effect as evidenced by the decrease in the level of BUN, serum creatinine and uric acid induced by Fenitrothion. The nephroprotective effect was previously described for Physalis (Moneim and El-Deib, 2012). Punica (Parmar 
and Kar, 2008) and silymarin (Karimi et al., 2005) by detoxifying excess urea and creatinine, free radical scavenging and antioxidant properties. In addition, other natural compounds with antioxidant activity as green tea were previously reported to protect against fenitrothion effects on kidney (Elhalwagy et al., 2008).

It is well documented that antioxidants play an important role in ameliorating the damaging effects of oxidative stress on cells. According to the results obtained in the current study, oral administration of Physalis, Punica and silymarin before fenitrothion normalized the oxidative stress biomarkers; CAT, GSH and MDA in liver, brain and kidney which were altered by Fenitrothion. This could be attributed to their potent antioxidant activity and free radical scavenging capability (Ramadan and Morsel, 2003).

Previous studies have suggested that the antioxidant activity of Physalis may be due to flavonoids, phenols and high amounts of vitamins (A,B and C) as well as the presence of essential minerals, magnesium, calcium, potassium, sodium and phosphorus which are classified as macronutrients (Wu et al., 2005). Also, (Turk et al., 2008) reported that there was a significant decrease in malondialdehyde (MDA) level and a marked increases in reduced glutathione (GSH), GPx and CAT activities, and vitamin $\mathrm{C}$ level in rats treated with different doses of Punica juice. Similarly, (Karimi et al., 2005) reported similar actions of silymarin on oxidative stress biomarker in rats treated with cisplatin.

\section{CONCLUSION}

In conclusion, excessive use of pesticides in agricultural schedules causes potential health hazards in human and animals in different organs including hepatic damage, neurological and renal disorders. The use of Physalis and Punica as dietary supplement was able to protect from pesticide-induced hepatotoxicity and its possible complications on the brain and kidney. It seems wise - at this point - to advice people susceptible to toxicity by pesticides to include Physalis and Punica in their daily food level as they were shown to protect against pesticide-induced hepatotoxicity, neurotoxicity and nephrotoxicity.

These protective actions might be attributed to their antioxidant properties acting as free radical scavengers and inhibitors of lipid peroxidation and a plasma membrane stabilizer. Further analysis of the constituents of Physalis and Punica is required to characterize and possibly isolate the ingredients that mediated these protective actions.

\section{Conflict of interest}

The authors declare that they have no conflict of interest.

\section{ACKNOWLEDGMENTS:}

This work was funded by the Academy for Scientific Research and Technology, Egypt (R11/2013-25/05/2014).

\section{REFERENCES}

1. Al-Attar, A.M. (2010). Physiological and histopathological investigations on the effects of alpha-lipoic acid in rats exposed to malathion. $\mathrm{J}$ Biomed Biotechnol 2010, 203503.

2. Albrecht, J. and Jones, E.A. (1999). Hepatic encephalopathy: molecular mechanisms underlying the clinical syndrome. J Neurol Sci 170, 138-146.

3. Arun, M. and Asha, V.V. (2007). Preliminary studies on antihepatotoxic effect of Physalis peruviana Linn. (Solanaceae) against carbon tetrachloride induced acute liver injury in rats. J Ethnopharmacol 111, 110-114.

4. Bartling, A.; Worek, F.; Szinicz, L. and Thiermann, H. (2007). Enzyme-kinetic investigation of different sarin analogues reacting with human acetylcholinesterase and butyrylcholinesterase. Toxicology 233, 166-172. 
5. Basu, A. and Penugonda, K. (2009). Pomegranate juice: a heart-healthy fruit juice. Nutr Rev 67, 49-56.

6. Beutler, E.; Duron, O. and Kelly, B.M., (1963). Improved method for the determination of blood glutathione. J Lab Clin Med 61, 882-888.

7. Borroni, G.; Maggi, A.; Sangiovanni, A.; Cazzaniga, M. and Salerno, F. (2000). Clinical relevance of hyponatraemia for the hospital outcome of cirrhotic patients. Dig Liver Dis 32, 605-610.

8. Bosoi, C.R.; Yang, X.; Huynh, J.; Parent-Robitaille, C.; Jiang, W.; Tremblay, M. and Rose, C.F. (2012). Systemic oxidative stress is implicated in the pathogenesis of brain edema in rats with chronic liver failure. Free Radic Biol Med 52, 1228-1235.

9. Brocardo, P.S.; Pandolfo, P.; Takahashi, R.N.; Rodrigues, A.L. and Dafre, A.L. (2005). Antioxidant defenses and lipid peroxidation in the cerebral cortex and hippocampus following acute exposure to malathion and/or zinc chloride. Toxicology 207, 283-291.

10. Castello, L.; Pirisi, M.; Sainaghi, P.P. and Bartoli, E. (2005). Hyponatremia in liver cirrhosis: pathophysiological principles of management. Dig Liver Dis 37, 73-81.

11. Celik, I.; Yilmaz, Z. and Turkoglu, V., (2009). Hematotoxic and hepatotoxic effects of dichlorvos at sublethal dosages in rats. Environ Toxicol 24, 128-132.

12. Coskun, O.; Kanter, M.; Korkmaz, A. and Oter, S., (2005). Quercetin, a flavonoid antioxidant, prevents and protects streptozotocin-induced oxidative stress and beta-cell damage in rat pancreas. Pharmacol Res 51, 117-123.

13. Desjardins, P.; Bandeira, P.; Raghavendra Rao, V.L.; Ledoux, S. and Butterworth, R.F. (1997). Increased expression of the peripheral-type benzodiazepine receptor-isoquinoline carboxamide binding protein mRNA in brain following portacaval anastomosis. Brain Res 758, 255-258.

14. Durak, D.; Uzun, F.G.; Kalender, S.; Ogutcu, A.; Uzunhisarcikli, M. and Kalender, Y. (2009). Malathion-induced oxidative stress in human erythrocytes and the protective effect of vitamins $\mathrm{C}$ and $\mathrm{E}$ in vitro. Environ Toxicol 24, 235242.

15. El-Demerdash, F.M. (2011). Lipid peroxidation, oxidative stress and acetylcholinesterase in rat brain exposed to organophosphate and pyrethroid insecticides. Food Chem Toxicol 49, 1346-1352.

16. Elhalwagy, M.E.A.; Darwish, N.S. and Zaher, E.M. (2008). Prophylactic effect of green tea polyphenols against liver and kidney injury induced by fenitrothion insecticide. Pesticide Biochemistry and Physiology 91, 81-89.

17. Ellman, G.L.; Courtney, K.D.; Andres, V. Jr. and Feather-Stone, R.M. (1961). A new and rapid colorimetric determination of acetylcholinesterase activity. Biochem Pharmacol 7, 88-95.

18. Faria, A.; Monteiro, R.; Mateus, N.; Azevedo, I. and Calhau, C. (2007). Effect of pomegranate (Punica granatum) juice intake on hepatic oxidative stress. Eur J Nutr 46, 271-278.

19. Ferenci, P.; Lockwood, A.; Mullen, K.; Tarter, R.; Weissenborn, K. and Blei, A.T. (2002). Hepatic encephalopathy-definition, nomenclature, diagnosis, and quantification: final report of the working party at the 11th World Congresses of Gastroenterology, Vienna, 1998. Hepatology 35, 716-721.

20. Franco, J.L.; Posser, T.; Mattos, J.J.; Trevisan, R.; Brocardo, P.S.; Rodrigues, A.L.; Leal, R.B.; Farina, M.; Marques, M.R.; Bainy, A.C. and Dafre, A.L. (2009). Zinc reverses malathion-induced impairment in antioxidant defenses. Toxicol Lett 187, 137-143. 
21. Galal, R.M.; Zaki, H.F.; Seif El-Nasr, M.M. and Agha, A.M. (2012). Potential protective effect of honey against paracetamol-induced hepatotoxicity. Arch Iran Med 15, 674-680.

22. George, J. (2006). Mineral metabolism in dimethylnitrosamine-induced hepatic fibrosis. Clin Biochem 39, 984-991.

23. Giri, S.; Prasad, S.B.; Giri, A. and Sharma, G.D. (2002). Genotoxic effects of malathion: an organophosphorus insecticide, using three mammalian bioassays in vivo. Mutat Res 514, 223231.

24. Harrison, M.J.; Marsden, C.D. and Jenner, P. (1979). Effect of experimental ischemia on neurotransmitter amines in the gerbil brain. Stroke 10, 165-168.

25. Hazarika, A.; Sarkar, S.N.; Hajare, S.; Kataria, M. and Malik, J.K., 2003. Influence of malathion pretreatment on the toxicity of anilofos in male rats: a biochemical interaction study. Toxicology 185, 1-8.

26. Hertz, L.; Yu, A.C.; Kala, G. and Schousboe, A. (2000). Neuronalastrocytic and cytosolic-mitochondrial metabolite trafficking during brain activation, hyperammonemia and energy deprivation. Neurochem Int 37, 83-102.

27. Hillman, J.V. (1994). Emergency care of insecticide poisonings. J Fla Med Assoc 81, 750-752.

28. Jager, A.K. and Saaby, L. (2011). Flavonoids and the CNS. Molecules 16, 1471-1485.

29. Jalan, R.; Shawcross, D. and Davies, N. (2003). The molecular pathogenesis of hepatic encephalopathy. Int J Biochem Cell Biol 35, 1175-1181.

30. Kalender, S.; Uzun, F.G.; Durak, D.; Demir, F. and Kalender, Y. (2010). Malathion-induced hepatotoxicity in rats: the effects of vitamins $\mathrm{C}$ and $\mathrm{E}$. Food Chem Toxicol 48, 633-638.

31. Kalender, Y.; Uzunhisarcikli, M.; Ogutcu, A.; Acikgoz, F. and Kalender,
S., 2006. Effects of diazinon on pseudocholinesterase activity and haematological indices in rats: The protective role of Vitamin E. Environ Toxicol Pharmacol 22, 46-51.

32. Karimi, G., Ramezani, M. and Tahoonian, Z., 2005. Cisplatin nephrotoxicity and protection by milk thistle extract in rats. Evid Based Complement Alternat Med 2, 383-386.

33. Kaur, G., Jabbar, Z., Athar, M. and Alam, M.S., 2006. Punica granatum (pomegranate) flower extract possesses potent antioxidant activity and abrogates Fe-NTA induced hepatotoxicity in mice. Food Chem Toxicol 44, 984-993.

34. Korany, N.S. and Ezzat, B.A., 2011. Prophylactic effect of green tea and Nigella sativa extracts against fenitrothion-induced toxicity in rat parotid gland. Arch Oral Biol 56, 13391346.

35. Kumar, R., Roy, S., Rishi, R. and Sharma, C.B., 1993. Metabolic fate of fenitrothion in liver, kidney and brain of rat. Biomed Chromatogr 7, 301-305.

36. Kurowska, E.M., Spence, J.D., Jordan, J., Wetmore, S., Freeman, D.J., Piche, L.A. and Serratore, P., 2000. HDLcholesterol-raising effect of orange juice in subjects with hypercholesterolemia. Am J Clin Nutr 72, 1095-1100.

37. Lansky, E.P., 2006. Beware of pomegranates bearing $40 \%$ ellagic Acid. J Med Food 9, 119-122.

38. Lansky, E.P. and Newman, R.A., 2007. Punica granatum (pomegranate) and its potential for prevention and treatment of inflammation and cancer. J Ethnopharmacol 109, 177-206.

39. Larsen, F.S., Gottstein, J. and Blei, A.T., 2001. Cerebral hyperemia and nitric oxide synthase in rats with ammoniainduced brain edema. J Hepatol 34, 548554.

40. Lasram, M.M., Annabi, A.B., El Elj, N., Selmi, S., Kamoun, A., El-Fazaa, S. and 
G. N. (2009). Metabolic disorders of acute exposure to malathion in adult Wistar rats. J Hazard Mater 163, 10521055.

41. Lowe, I.P.; Robins, E. and Eyerman, G.S. (1958). The fluorometric measurement of glutamic decarboxylase and its distribution in brain. $\mathbf{J}$ Neurochem 3, 8-18.

42. Mansour, H.H.; Hafez, H.F. and Fahmy, N.M. (2006). Silymarin modulates Cisplatin-induced oxidative stress and hepatotoxicity in rats. J Biochem Mol Biol 39, 656-661.

43. McCormick, P.A. and Donnelly, C. (2008). Management of hepatorenal syndrome. Pharmacol Ther 119, 1-6.

44. Medina, J. and Moreno-Otero, R. (2005). Pathophysiological basis for antioxidant therapy in chronic liver disease. Drugs $65,2445-2461$.

45. Moneim, A.E.A. and El-Deib, K.M. (2012). The Possible protective effects of Physalis peruviana on carbon tetrachloride-induced nephrotoxicity in male albino rats. Life Science JournalActa Zhengzhou University Overseas Edition 9, 1038-1052.

46. Nassuato, G.; Iemmolo, R.M.; Strazzabosco, M.; Lirussi, F.; Deana, R.; Francesconi, M.A.; Muraca, M.; Passera, D.; Fragasso, A.; Orlando, R. (1991). Effect of Silibinin on biliary lipid composition. Experimental and clinical study. J Hepatol 12, 290-295.

47. Ncibi, S.; Ben Othman, M.; Akacha, A.; Krifi, M.N. and Zourgui, L. (2008). Opuntia ficus indica extract protects against chlorpyrifos-induced damage on mice liver. Food Chem Toxicol 46, 797802.

48. Norenberg, M.D.; Jayakumar, A.R. and Rama Rao, K.V., 2004. Oxidative stress in the pathogenesis of hepatic encephalopathy. Metab Brain Dis 19, 313-329.
49. Ogutcu, A.; Suludere, Z. and Kalender, Y. (2008). Dichlorvos-induced hepatotoxicity in rats and the protective effects of vitamins $\mathrm{C}$ and E. Environ Toxicol Pharmacol 26, 355-361.

50. Parmar, H.S. and Kar, A., (2008). Medicinal values of fruit peels from Citrus sinensis, Punica granatum, and Musa paradisiaca with respect to alterations in tissue lipid peroxidation and serum concentration of glucose, insulin, and thyroid hormones. J Med Food 11, 376-381.

51. Pitts, T.O. and Van Thiel, D.H. (1986). Disorders of the serum electrolytes, acidbase balance, and renal function in alcoholism. Recent Dev Alcohol 4, 311339.

52. Possamai, F.P.; Fortunato, J.J.; Feier, G.; Agostinho, F.R.; Quevedo, J.; Wilhelm F. D. and Dal-Pizzol, F. (2007). Oxidative stress after acute and subchronic malathion intoxication in Wistar rats. Environ Toxicol Pharmacol 23, 198-204.

53. Pradeep, K.; Mohan, C.V.; Gobianand, K. and Karthikeyan, S. (2007). Silymarin modulates the oxidant-antioxidant imbalance during diethylnitrosamine induced oxidative stress in rats. Eur $\mathbf{J}$ Pharmacol 560, 110-116.

54. Prakash, R. and Mullen, K.D. (2010). Mechanisms, diagnosis and management of hepatic encephalopathy. Nat Rev Gastroenterol Hepatol 7, 515-525.

55. Prasanthi, K.; Muralidhara and Rajini, P.S., (2005). Morphological and biochemical perturbations in rat erythrocytes following in vitro exposure to Fenvalerate and its metabolite. Toxicol in Vitro 19, 449-456.

56. Ramadan, M.F. and Moersel, J.T. (2007). Impact of enzymatic treatment on chemical composition, physicochemical properties and radical scavenging activity of goldenberry (Physalis peruviana L.) juice. Journal of 
the Science of Food and Agriculture 87, 452-460.

57. Ramadan, M.F. and Morsel, J.T. (2003). Oil goldenberry (Physalis peruviana L.). J Agric Food Chem 51, 969-974.

58. Ross, M.G. and Desai, M. (2005). Gestational programming: population survival effects of drought and famine during pregnancy. Am J Physiol Regul Integr Comp Physiol 288, R25-33.

59. Schepke, M. (2007). Hepatorenal syndrome: current diagnostic and therapeutic concepts. Nephrol Dial Transplant 22 Suppl 8, viii2-viii4.

60. Seeram, N.P.; Adams, L.S.; Henning, S.M.; Niu, Y.; Zhang, Y.; Nair, M.G. and Heber, D. (2005). In vitro antiproliferative, apoptotic and antioxidant activities of punicalagin, ellagic acid and a total pomegranate tannin extract are enhanced in combination with other polyphenols as found in pomegranate juice. $\mathrm{J}$ Nutr Biochem 16, 360-367.

61. Shaker, E.; Mahmoud, H. and Mnaa, S. (2010). Silymarin, the antioxidant component and Silybum marianum extracts prevent liver damage. Food Chem Toxicol 48, 803-806.

62. Singh, R.P.; Chidambara Murthy, K.N. and Jayaprakasha, G.K. (2002). Studies on the antioxidant activity of pomegranate (Punica granatum) peel and seed extracts using in vitro models. J Agric Food Chem 50, 81-86.

63. Sinha, A.K. (1972). Colorimetric assay of catalase. Anal Biochem 47, 389-394.

64. Sonnewald, U.; Therrien, G. and Butterworth, R.F. (1996). Portacaval anastomosis results in altered neuron-astrocytic metabolic trafficking of amino acids: evidence from 13C-NMR studies. J Neurochem 67, 1711-1717.

65. Subash, S. and Subramanian, P., 2008. Effect of morin on the levels of circulatory liver markers and redox status in experimental chronic hyperammonaemic rats. Singapore Med J 49, 650-655.

66. Subash, S. and Subramanian, P. (2009). Morin a flavonoid exerts antioxidant potential in chronic hyperammonemic rats: a biochemical and histopathological study. Mol Cell Biochem 327, 153-161.

67. Swapna, I.; Kumar, K.V.; Reddy, P.V.; Murthy Ch, R.; Reddanna, P. and Senthilkumaran, B. (2006). Phospholipid and cholesterol alterations accompany structural disarray in myelin membrane of rats with hepatic encephalopathy induced by thioacetamide. Neurochem Int 49, 238-244.

68. Toklu, H.Z.; Dumlu, M.U.; Sehirli, O.; Ercan, F.; Gedik, N.; Gokmen, V. and Sener, G. (2007). Pomegranate peel extract prevents liver fibrosis in biliaryobstructed rats. J Pharm Pharmacol 59, 1287-1295.

69. Turk, G.; Sonmez, M.; Aydin, M.; Yuce, A.; Gur, S.; Yuksel, M.; Aksu, E.H. and Aksoy, H. (2008). Effects of pomegranate juice consumption on sperm quality, spermatogenic cell density, antioxidant activity and testosterone level in male rats. Clin Nutr 27, 289-296.

70. Vaquero, J.; Chung, C. and Blei, A.T. (2003). Brain edema in acute liver failure. A window to the pathogenesis of hepatic encephalopathy. Ann Hepatol 2, 12-22.

71. Wang, C.J.; Wang, J.M.; Lin, W.L.; Chu, C.Y.; Chou, F.P. and Tseng, T.H. (2000). Protective effect of Hibiscus anthocyanins against tert-butyl hydroperoxide-induced hepatic toxicity in rats. Food Chem Toxicol 38, 411-416.

72. Wasan, K.M.; Najafi, S.; Wong, J.; Kwong, M. and Pritchard, P.H. (2001). Assessing plasma lipid levels, body weight, and hepatic and renal toxicity following chronic oral administration of a water soluble phytosterol compound, 
FM-VP4, to gerbils. J Pharm Pharm Sci 4, 228-234.

73. Wong, F. and Blendis, L., 1994. Pathophysiology of sodium retention and ascites formation in cirrhosis: role of atrial natriuretic factor. Semin Liver Dis 14, 59-70.

74. Wu, S.J.; Ng, L.T.; Chen, C.H.; Lin, D.L.; Wang, S.S. and Lin, C.C. (2004). Antihepatoma activity of Physalis angulata and $\mathrm{P}$. peruviana extracts and their effects on apoptosis in human Hep G2 cells. Life Sci 74, 2061-2073.

75. Wu, S.J.; Ng, L.T.; Huang, Y.M.; Lin, D.L.; Wang, S.S.; Huang, S.N. and Lin, C.C. (2005). Antioxidant activities of Physalis peruviana. Biol Pharm Bull 28, 963-966.

76. Yoshioka, T.; Kawada, K.; Shimada, T. and Mori, M. (1979). Lipid peroxidation in maternal and cord blood and protective mechanism against activated- oxygen toxicity in the blood. Am J Obstet Gynecol 135, 372-376.

77. Youdim, K.A.; Qaiser, M.Z.; Begley, D.J.; Rice-Evans, C.A. and Abbott, N.J. (2004). Flavonoid permeability across an in situ model of the blood-brain barrier. Free Radic Biol Med 36, 592-604.

78. Yousef, M.I.; Awad, T.I. and Mohamed, E.H. (2006). Deltamethrin-induced oxidative damage and biochemical alterations in rat and its attenuation by Vitamin E. Toxicology 227, 240-247.

79. Zielinska, M.; Hilgier, W.; Law, R.O.; Gorynski, P. and Albrecht, J. (2002). Effects of ammonia and hepatic failure on the net efflux of endogenous glutamate, aspartate and taurine from rat cerebrocortical slices: modulation by elevated $\mathrm{K}+$ concentrations. Neurochem Int 41, 87-93.

$$
\begin{aligned}
& \text { التكميل الغذائي بالبونيكا والفيساليس يقلل التتاثير الضار للفينيتروثيون في الجرذان. } \\
& \text { رشا عبد الغتي - اباء محمد ـ شيماء انيس- احمد بحيري - وليد بركات }
\end{aligned}
$$

التعرض للمبيدات الحشرية قد يؤدي الي العديد من المخاطر الصحية مثل خلل الكبد والذي قد يتبعه خلل في وظائف المخ

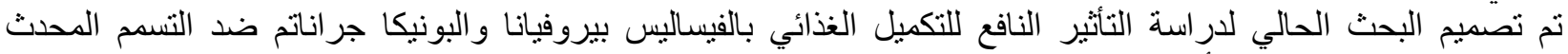

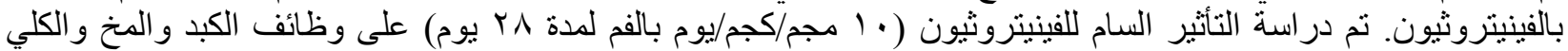

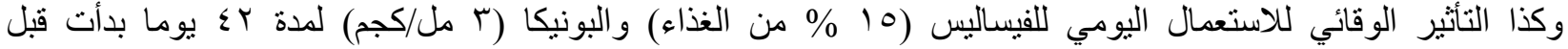

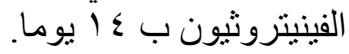

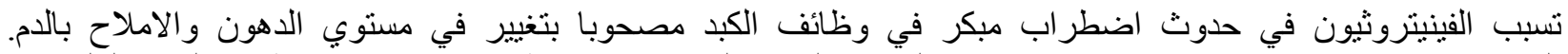

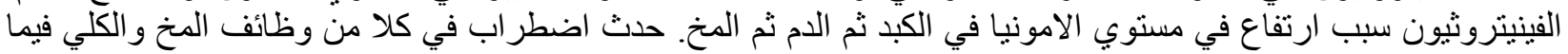

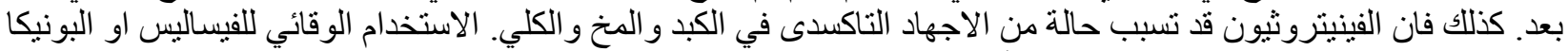

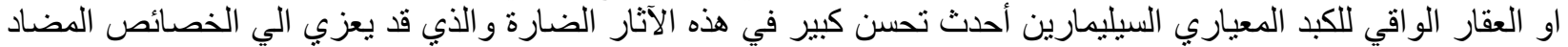
ل للاكسدة لهذه المركبات. هذه النتائج تتشير الئ امكانية استخدام الفيساليس و البونيكا مستقبلا في علاج التسمم بالمبيدات الحشرية بعد اجراء المزيد من الاختبار ات لتحديد المو اد الفعالة المسئولة عن هذه الانشطة الوقائية. 